\title{
Panopticism and Totalitarian Space
}

\begin{abstract}
Saladdin Ahmed ${ }^{1}$
In an era of digital surveillance cameras and drones, it is extremely important to understand the preoccupation of modern governments with unlimited spatial transparency, in addition to the ways in which this fixation underlies prevailing spatial technologies of power. We have increasingly become objects of the gaze of power in an extended space that is coming to resemble a surface on which everything is completely visible, identifiable, and eliminable. I argue that today's spatial technologies of power have built upon principles of panopticism to produce a unified space that can best be described as totalitarian. To grasp the totalitarian features of the produced space, a re-consideration of Foucault's concept of panopticism and its contemporary applications will prove helpful. In brief, panopticism is a method of rendering power both all-seeing and all-knowing for the purpose of achieving unlimited control over social space. My article is divided into three main sections: a return to the model of the Panopticon, an analysis of the principles of panopticism in light of Foucault's account, and a concluding discussion of the increasingly totalitarian space in which we find ourselves. [Article copies available for a fee from The Transformative Studies Institute. E-mail address: journal@transformativestudies.org Website: http://www.transformativestudies.org [02018 by The Transformative Studies Institute. All rights reserved.]
\end{abstract}

KEYWORDS: Panopticism, Space, Foucault, Transparency.

The degree to which contemporary social space has been made transparent to the gaze of power, controlled by the state's apparatuses and corporate partners, is unprecedented. Today, the state of being

\footnotetext{
${ }^{1}$ Saladdin Ahmed, Ph.D., is O'Donnell Visiting Assistant Professor at Whitman College, WA. He holds a Ph.D. in Philosophy from the University of Ottawa and specializes in social and political philosophy, Critical Theory, and philosophy of space. His academic publications to-date focus on Critical Theory, Foucault, and Nietzsche. He has also published commentaries and op-eds in online outlets including The Jerusalem Post, Huffington Post (German Edition), openDemocracy, Al-Jazeera-English, and CounterPunch. Address correspondence to: Saladdin Ahmed; e-mail: saladdin.ahmed@gmail.com.
} 